\title{
Protagoras wydobyty z Teajteta
}

Zbigniew Nerczuk, Miarajest każdy z nas. Projekt zwolenników zmienności rzeczy w Platońskim „Teajtecie” na tle myśli sofistycznej, Wydawnictwo Naukowe UMK, Toruń 2009, ss. 205.

MARIAN WESOEY / Poznań /

Pomysłowy tytuł powyższej książki stanowi wyborną parafrazę słynnej formuły Protagorasa, streszczanej zwykle w łacińskich słowach: Homo mensura. Nieodzowny tutaj podtytuł (być może nieco przydługi) uprzedza już Czytelnika o podjętej przez Autora problematyce zawartej w Platońskim Teajtecie. Dialog ten potraktowany został ambitnie i zachęcająco jako jedno z tych źródłowych świadectw na temat poglądów Protagorasa oraz sofistów w ogóle, które nie zostało jeszcze dotąd należycie zinterpretowane. Oprócz „Wstępu” (poszerzonego o „Wprowadzenie do dialogu Teajtet”), „Zakończenia” i „Bibliografii”, rozprawa składa się z czterech rozdziałów problemowych: „I. Koncepcja metaksy”, „II. Wizja zmiennej rzeczywistości”, „III. Stanowisko epistemologiczne zwolenników zmienności w Teajtecie a sofistyka”, „IV. Dialog Teajtet a sofistyczna koncepcja języka”. W rozdziałach tych wyróżnione są dalsze, dość szczegółowe nagłówki tematyczne, których nie ma tutaj potrzeby przytaczać.

Ogólny cel rozprawy sformułowany został w sposób następujący: „Praca ta jest próbą ponownego rozpatrzenia stanowiska przedstawionego przez niemałe grono badaczy, którzy przyjmowali, że przekaz w Teajtecie stanowić może podstawę rekonstrukcji poglądów Protagorasa czy, ogólniej, perspektywy reprezentowanej przez przedstawicieli ruchu sofistycznego. U źródła tego zamierzenia leży przekonanie o olbrzymim znaczeniu referatu zawartego w Teajtecie dla zrozumienia poglądów Protagorasa oraz całej sofistyki, a także wiara w to, iż konieczne jest podjęcie dyskusji na temat atrybucji przedstawionych w dialogu poglądów” (s. 23, podkreśl. moje - M.W.). Po uważnej lekturze tej wielowątkowej rozprawy nasuwają się pewne refleksje, które zwięźle zostaną tutaj 
podane w celu nie tylko ustosunkowania się do treści wywodów, ale także wskazania możliwości podejścia nieco odmiennego.

$\mathrm{W}$ rozprawie tej odnajdujemy trochę powtórzeń związanych z pewnymi niejasnościami czy trudnościami interpretacyjnymi. Autor może niepotrzebnie przywołuje przy tym aż tak obszerną literaturę przedmiotu z różnych lat (także tę dawniejszą), skoro z pewnością wystarczyłoby ograniczenie się do najbardziej miarodajnych, nowszych opracowań na temat sofistów, Protagorasa i Platona. W twórczej pracy naukowej przytaczanie wielu różnych stanowisk badawczych szkodzi zwykle spójności wywodów (chociaż świadczy to zarazem o tym, iż Autor jest szeroko zorientowany w rozważanym przedmiocie i włożył weń wiele trudu badawczego). Z pewnością natomiast z nowszych i twórczych ujęć interpretacyjnych, koncentrujących się na tym, kim byli sofiści, należałoby uwzględnić oryginalny artykuł Giseli Stryker pt. Methods of Sophistry z 1996 r., który Autor co prawda podaje w swej Bibliografii, nie wykorzystuje go jednak. Dotyczy on samej interpretacji historyczno-problemowej sofistyki, we właściwym dla niej kontekście, terminologii i rekonstrukcji źródłowej. Jest to zapomniana, lecz wciąż niesłychanie ważna próba odpowiedzi historycznej na pytanie o to, kim właściwie byli sofiści: filozofami, retorami czy dialektykami.

Oprócz nadmiernego dokumentowania wywodów dawniejszymi pracami, druga znacznie poważniejsza - trudność w rozpoznaniu głównych tez recenzowanej rozprawy dotyczy samej metody wykorzystania Teajteta Platona. Otóż wpierw należałoby uchwycić strukturalnie całokształt tego tekstu. Mamy tutaj wszak do czynienia z niesamowitym w swej formie i treści „kąskiem”, liczącym ponad 30 stron, we wzorcowym wydaniu dialogu Teajtet $(152$ a -183 c). Następnie w świetle nowszych opracowań (zob. G. Casertano (ed.), Il Teeteto di Platone: struttura e problematiche, Napoli 2002) należałoby rozpoznać w całej tej partii dialogu wymyślny scenariusz Platona, podług którego odpiera on stopniowo Protagorasa, wychodząc od jego własnych tudzież odpowiednio spreparowanych założen. Przy bliższej lekturze tekstu wyróżnić w nim można pięć kolejnych interpretacji Protagorasa zakończonych pewnymi wnioskami. Tymi interpretacjami są najpierw trzy sekwencje: (1) $152 \mathrm{a}-155 \mathrm{~d}$; (2) $155 \mathrm{e}-157 \mathrm{~d}$; (3) $157 \mathrm{~d}-161$ a (które to w iście dramaturgiczny sposób przerywane są konwersacjami Sokratesa z Teodorem i Teajtetem oraz niesamowitą „Apologią Protagorasa”), po czym następują dwie finalne sekwencje: (4) $170 \mathrm{a}-172 \mathrm{c}$; (5) $177 \mathrm{c}-179 \mathrm{~d}$ (a dalej tematyczne przejście do poglądów heraklitejczyków).

Pomijając pewne drobniejsze szczegóły, stwierdzić możemy, że dopiero takie rozpoznanie kontekstu, całej złożoności i sekwencji dialogu pozwala nam ustosunkować się do przedmiotu, metody i problematyki recenzowanej książki. W kontekście samego jej tytułu oraz tego, iż najważniejszą tezą Protagorasa było słynne stwierdzenie, że „człowiek jest miarą wszystkiego", dziwić może potraktowanie tego problemu jedynie w podrozdziale 1.2. Homo-mensura" (na niespełna sześciu stronach), nie zaś jako zasadniczego rozdziału. Przecież w Platońskim Teajtecie ten logos Protagorasa był de facto wyjściowy i stanowił on wyzwanie dla dalszych zawrotnych wywodów, adaptacyjnych skojarzeń i wymyśl nych refutacji. Wbrew temu Autor wychodzi jednak od kwestii (moim zdaniem) wtór- nych, stawiając w rozdziale pierwszym tzw. „koncepcję metaksy” $i$ „atrybucję „tajemnej nauki”, przenosząc zarazem akcent na inne (równie dziwnie nazwane) wątki tematyczne Teajteta.

Z pewnością do enigmatycznego tytułu oraz treści rozdziału I (Koncepcja metaksy”) można mieć pewne zastrzeżenia. Nawet bowiem komuś, kto czyta Teajteta w oryginale, trudno jest na wstępie ustalić, co Autor ma na myśli. Nie wydaje się zasadne takie użycie przyimka metaxy, który zrozumiały jest tylko w kontekście (powstałej niejako w wyniku pars pro toto) formuły o niejasnym sensie „koncepcja metaksy”, którą autor rozprawy posługuje się nadmiernie. Otóż w całym tym dialogu przyimek metaxy pojawia się sześć razy, a tylko w jednym passusie (156 d6) w nawiązaniu do rzeczonej kwestii. Autor trafnie kreśli jednak zaplecze filozofii przyrody w tym aspekcie, w związku z czym pozostaje stwierdzić, iż należało tę koncepcję postrzegania określić jakoś bardziej sensownie i merytorycznie. Zapewne Z. Nerczuk zbytnio uzależniony był w tym względzie od dość nieprzemyślanej terminologii w literaturze przedmiotu. Równie niewłaściwe jest także operowanie określeniem „tajemnej nauki” (secret doctrine, Geheimlehre). Trudno wszak mówić tu o „nauce”, skoro grecki logos oznacza raczej wypowiedź, wywód, argument itp. By uchwycić sedno problemu, należy dokładnie zacytować następującą wypowiedź Sokratesa (wraz ze znakiem zapytania): „Czyżby więc, na Charyty, wszechmądry był ten Protagoras, skoro nam niby licznemu pospólstwu wypowiedział (ฤ̉víłato) to zagad-

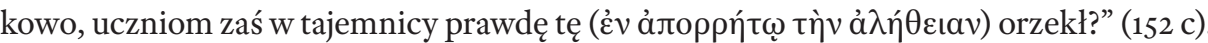

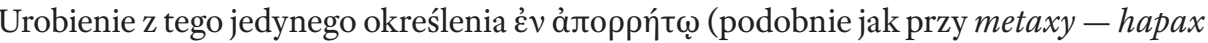
legomenon), zresztą ze znakiem zapytania, pojęcia „tajemnej nauki” wydaje się nadinterpretacja. Nieco dalej Platoński Sokrates, może z lekkim odcieniem ironii, nazywa

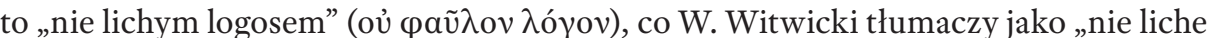
słowo" - 151 e oraz $152 \mathrm{~d}$ ).

Po cóż miał Protagoras swą tak ważną Prawdę podawać w tajemnicy tylko wybranym uczniom? Czyż byłoby to w stylu sofistów, którzy zwykli wszak wystepować publicznie ze swymi epideixeis? Na tak postawione pytania nie zdołamy zapewne przekonująco udzielić ostatecznej odpowiedzi, wszelako powinniśmy jak najgłębiej wniknąc w egzegezę tekstów źródłowych, próbując uniknąć wszelkiego rodzaju nadinterpretacji. Szkoda również, że Autor nie uwzględnił przy tym pewnych wątków myśli Protagorasa, pojawiających się w dialogu nazwanym przez Platona od jego imienia, a także w tytułowym dialogu Sofista. W tym zakresie nowsze studia (głównie badaczy włoskich) są nader inspirujące. W dawniejszej literaturze przedmiotu nie starano się rozpoznać Gorgiasza i Protagorasa jako tych, którzy podnosili także kwestie fizyczne (przyrodnicze). Jeden z przewijających sie wątków tematycznych w recenzowanej rozprawie dotyczy właśnie tego aspektu. Na wsparcie tej tezy można tutaj przytoczyć dwa pierwszoplanowe świadectwa. Autor anonimowego pisma Dissoi logoi (z końca $V$ w.) podaje niejako programowe zajmowanie się peri physios hapanton. Jest to świadectwo odbywanych wówczas przez sofistów deklamacji publicznych (epideixeis) także o naturze wszechrzeczy, zapewne konkurencyjnych wobec ówczesnej filozofii przyrody. Odnośnie do związków języka, wiedzy i działania w Dissoi logoi przeczytać możemy $(8,1-3)$ o: „nauczaniu o naturze 


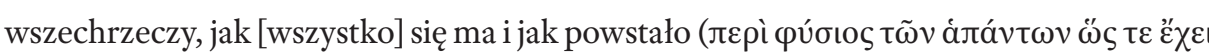

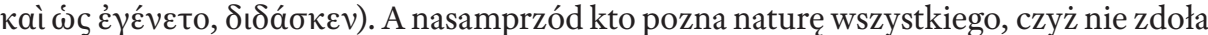

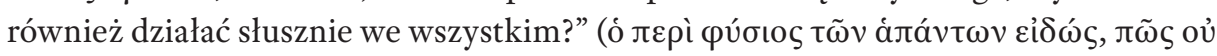

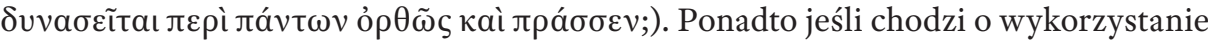
Sofisty Platona, to niezwykle ważne jest pochodzące właśnie z tego dialogu świadectwo (232 b-e), według którego z ,antylogicznie” przez sofistów dyskutowanych kwestii jedne dotyczyły bogów, wszystkiego, co jawne na ziemi i niebie, powstawania i bytu, a także praw, polityki i wszelkich sztuk. Sofiści podnosili także kwestię różnicy między wytworami natury a zwyczajami stanowionymi przez ludzi. Inaczej mówiąc, sofiści zajmowali się teologią, kosmologią, polityką i dziedzinami sztuk (technai).

Istotne w rozprawie są rozdziały problemowe II-IV, chociaż cechują się one nadmiernym rozczłonkowaniem $\mathrm{w}$ analizie poszczególnych wyrażeń $\mathrm{i}$ wątków tematycznych Teajteta. Przed czytelnikiem, który nie wniknął wystarczająco w kompozycję tego dialogu Platona, znika z pola widzenia jego oryginalna wewnętrzna perspektywa, która przecież jest tu tekstowym podłożem. $Z$ drugiej zaś strony pamiętać trzeba o wszelkich problemach związanych z rekonstrukcją owego protagorejskiego czy sofistycznego zaplecza. Niekiedy naprawdę trudno jest zorientować się w szczególach linii argumentacyjnej Autora. Zapewne rozprawy tej nie można traktować jako komentarza do wspomnianej partii owego niezwykle złożonego dialogu Platona. Wiadomo zresztą, iż nie taki był cel Autora, który przedkładając swą propozycję wyłuskania z Teajteta ważnych świadectw, stwierdził zarazem, że dialog ten jest „prawdziwą skarbnicą motywów sofistycznych" (s. 192). Gdyby tak było faktycznie, wówczas skromne testimonia wzięte z Teajteta przez Dielsa-Kranza należałoby tutaj znacząco rozpoznać i poszerzyć. Pozostaje jednak pewna podstawowa trudność.

Otóż zasadniczą kwestią jest to, na ile Platon był wiarygodny w swoim przedstawianiu postaci, motywów, spięć i scenerii dyskusyjnych? Wiadomo, że nawet swego protagonistę Sokratesa zmyślnie wykreował, przedstawiając go niekiedy w rubasznym, a czasem nawet ambiwalentnym świetle. Cóż należy zatem powiedzieć o oponentach Sokratesa, którymi byli przede wszystkim sofiści, jak o tym świadczą już same tytuły dialogów. Podobno jedynie Demokryta zbył Platon milczeniem. Z antycznych autorów zwłaszcza Atenajos w Sofistach przy uczcie (215 c - 220 a; 504 e - 509 e) wskazywał na złośliwe wymysły Platona, który nie trzymał się historycznych realiów, także co do osoby Protagorasa (zob. M. Trapp, Plato in the Deipnosophistae, w: D. Braund and J. Wilkins (eds.), Athenaeus and his World. Reading Greek Culture in the Roman Empire, Exeter 200o, s. 353-363). Dzisiejszych badaczy wciąż nurtuje wymyślny i ambiwalentny stosunek Platona do wcześniejszych autorów (zob. zbiór artykułów pod red. M. Dixsaut i A. Brancacci, Platon, source des Présocratiques. Exploration, Paris 2002, s. 169-19o, gdzie uwzględniono także Protagorasa). Niezależnie od tego, czy jako czytelnicy i badacze Platona, zakładamy problemową i dramaturgiczną autentyczność wykładni jego dialogów, należy wystrzegać się zbytniego dociekania w tym względzie „prawdy historycznej”. Są to bowiem kompozycje literackie podług tego, co prawdopodobne bądź domyślne (eikos). Najogólniej rzecz ujmując, niepodobna ostatecznie ustalić, czy i, jeśli tak, to w jakim stopniu przedstawione w Protagorasie i Teajtecie dyskusyjne agony z Sokratesem nie były przypadkiem tylko Platońską wymyślną inscenizacją, jedynie wzorowaną na pewnych realiach historycznych.

Nie ulega wszakże wątpliwości fakt, iż Platoński Sokrates miał w osobie Protagorasa niebywałego dyskutanta i nader trudnego oponenta w dwóch dialogach (Protagoras i Teajtet), które różnią się całkowicie co do swej dramaturgii i sytuacji problemowej. W endejktycznym Protagorasie główny spór dotyczy problemu, czy wszelka arete stanowi episteme (która ma większą wartość dla człowieka), natomiast w pejrastycznym Teajtecie dyskutowana jest trudność samego określenia episteme (mamy tutaj przede wszystkim nawiązanie do aisthesis i phantasia oraz żmudne odpieranie stanowiska Protagorasa, zwieńczone wyborna formułą inwersji, peritrope, którą miał już wcześniej wysunać przeciwko sofiście z Abdery jego krajan Demokryt). Jak dawniej starano się, aby Platoński Sokrates „przezwyciężyl” argumentację Gorgiasza i Protagorasa, tak dzisiaj — w ramach pewnej tendencji do rehabilitowania sofistów - starają się niektórzy badacze „przezwyciężyć" filozofię Platona i Arystotelesa. Są to współcześni rzecznicy modnego nihilizmu i postmodernizmu, głównie we Francji i Stanach Zjednoczonych, którzy chętnie powołują się na swych antycznych i niedocenionych w tym względzie sofistów. Przykładowo, dwie nośne pozycje: B. Cassin, L'effet sophistique, Paris 1995 (częściowo po włosku: Milano 2002) oraz S. Mailloux (ed.), Rhetoric, Sophistry, Pragmatism, Cambridge 1995. Ostatnio także u nas w wymiarze politologicznym: C. Mielczarski, Sofiści i polityka. Antyczne źródta liberalizmu europejskiego, Warszawa 2010. Trudno odgadnąć, w jakim stopniu Z. Nerczuk, autor publikacji o Gogiaszu i Protagorasie, podzielałby te modne dziś orientacje i adaptacyjne interpretacje. W każdym razie Jego nastawienie jest - jak się wydaje nader wartościujące w aspekcie rekonstrukcji autentycznych poglądów sofistów greckich. 